\section{Quebec's research resurrection}

\section{By Lev Osherovich, Senior Writer}

AstraZeneca plc and Pfizer Inc. have partnered with the Quebec government to form the not-for-profit Neomed Institute. The drug development institute will resume work on pain compounds discontinued by AstraZeneca earlier this year and plans to build a new pipeline through collaborations with regional academic laboratories and biotech startups.

The public-private partnership extends a lifeline to a team of AstraZeneca researchers who previously were developing preclinical pain therapeutics at the Montreal site. The pharma is winding down the bulk of its internal neurology $\mathrm{R} \& \mathrm{D}$ as part of a restructuring announced earlier this year. ${ }^{1}$

The institute is located in a former AstraZeneca R\&D center in Technoparc Montreal. Neomed has retained former AstraZeneca R\&D staff but has hired new management led by President and CEO Max Fehlmann. Fehlmann was formerly president and CEO of the Quebec Consortium for Drug Discovery, another regional translational science public-private partnership.

Neomed has secured C\$8 million (\$8.1 million) in upfront cash from the government of Quebec, along with a five-year, non-interest-bearing loan of C $\$ 20$ million (\$20.4 million). Pfizer is contributing C \$3.5 million ( $\$ 3.6$ million). AstraZeneca is contributing $\mathrm{C} \$ 5$ million ( $\$ 5.1$ million), as well as land and the facility, laboratory equipment and IP for three pain molecules.

Didier Jean-François, Neomed's VP of business development and marketing, said the startup money will be supplemented by additional fundraising and will give the institute at least five years of runway to build a pipeline that goes beyond the institute's core area of pain.

Jean-François previously was director of business development at Crucell N.V., which was acquired by Johnson \& Johnson in 2011.

Neomed will retain about half a dozen former AstraZeneca employees to continue their work on the three pain compounds, said Jean-François. Those projects will be spearheaded by Neomed CSO Philippe Walker, formerly VP and head of AstraZeneca R\&D in Montreal.

AstraZeneca said one of the donated compounds is a preclinical purinergic receptor P2X ligand-gated ion channel 3 (P2X3) antagonist in development for painful bladder syndrome and interstitial cystitis. Jean-François did not disclose the targets of the other two compounds.

"AstraZeneca's goal was to give the compounds to the people who had been developing them in-house," said Jean-François. "All of the IP for these pain compounds was given to Neomed, and if Neomed manages to develop these compounds to a commercial milestone," the institute's pharma partners Pfizer and AstraZeneca will both have the right of first negotiation to license these compounds.

Jean-François said that because the two pharma partners have different strategic goals it is unlikely that they both would want to compete for the same technology coming out of the institute. If the two pharmas do become interested in licensing the same technology, the right of first negotiation will likely go to the highest contributor to the institute's budget.

The two pharmas also will have rights of first negotiation for any additional technology emerging from the institute. AstraZeneca does not have clawback rights to its former compounds.

Jean-François added that he hopes to recruit at least two more pharmas into the partnership.

Meanwhile, Neomed is soliciting collaborative research proposals from academic researchers and startups. Jean-François said part of Neomed's operating expenses will be met by renting out floor space and laboratory facilities in its building.

Jean-François said Neomed has the capacity to in-license up to seven more preclinical projects and to advance them to the IND stage. $\mathrm{He}$ hopes to in-license early stage projects that are not far enough along toward translation to attract typical VC investors.

These programs do not necessarily have to come from Quebec-based researchers, but because the institute is funded in part by the Quebec regional government, one goal is to support the Quebec biotech industry.

"The Neomed Institute is a translational research center with its own pipeline, but we're also an incubator," said Jean-François. "We have a total of 15 staff, most of whom are working in discovery or development. We see ourselves as a development partner rather than as an exit for prior investors."

Osherovich, L. SciBX 5(48); doi:10.1038/scibx.2012.1249

Published online Dec. 13, 2012

\section{REFERENCES}

1. Hansen, S. BioCentury 20(8), A7; Feb. 20, 2012

\section{COMPANIES AND INSTITUTIONS MENTIONED}

AstraZeneca plc (LSE:AZN; NYSE:AZN), London, U.K. Johnson \& Johnson (NYSE:JNJ), New Brunswick, N.J. Neomed Institute, Montreal, Quebec, Canada

Pfizer Inc. (NYSE:PFE), New York, N.Y.

Quebec Consortium for Drug Discovery, Nuns' Island, Quebec, Canada 